\title{
ОСОБЛИВОСТІ ЗМІН БІОХІМІЧНИХ ПОКАЗНИКІВ КРОВІ ПІДДОСЛІДНИХ ТВАРИН ВНАСЛІДОК ПОЄДНАНОЇ АБДОМІНО-СКЕЛЕТНОЇ ТРАВМИ ТА ІШЕМІЇ-РЕПЕРФУЗІЇ НИЖНІХ КІНЦІВОК
}

Вступ. Поєднана травма - важливе питання сучасної медицини, оскільки є основною причиною смерті та тривалої втрати працездатності серед осіб молодого віку. До найбільш розповсюджених ускладнень належить остеоартроз, що спричиняє інвалідність. Несприятливим фрактором, що впливає на його розвиток, є ішемія-реперфузія кінцівки, однак їі вплив потребує додаткового вивчення.

Мета дослідження - вивчити вплив ішемії-реперфузії кінцівки на моделі поєднаної абдоміно-скелетної травми та масивної крововтрати на зміни біохімічних показників крові.

Методи дослідження. Робота має експериментальний характер, ї̈ виконували на 130-ти статевозрілих білих щурах-самцях лінії Вістар. Усіх тварин поділили на чотири групи: контрольну і три дослідних. До контрольної групи входили інтактні тварини, до 1-ї дослідної- щури, яким моделювали перелом стегна, масивну зовнішню крововтрату та ішемію-репероузію нижніх кінцівок, до 2-ї дослідної - тварини, яким моделювали скелетну травму, масивну зовнішню крововтрату і закриту травму органів черевної порожнини, до 3-ї дослідної - щури, яким моделювали закриту травму органів черевної порожнини, скелетну травму, масивну зовнішню крововтрату й ішемію-реперфузію нижніх кінцівок. Тварин дослідних груп виводили з експерименту через 3, 7, 14 та 21 добу після моделювання травм. У сироватці крові піддослідних тварин визначали рівень лужної і кислої фросфратаз та на основі цих даних розраховували індекс мінералізації.

Результати й обговорення. У піддослідних тварин усіх груп спостерігали тривале зростання активності лужної і кислої фросфратаз та, як наслідок, індексу мінералізації. Виявлено однотипність у динаміці змін досліджуваних показників у щурів 1-ї і 2-ї дослідних груп. У групі піддослідних тварин, яким моделювали абдоміно-скелетну травму, масивну крововтрату та ішемію-реперфузію нижніх кінцівок, їх зміни були найбільш вираженими, зокрема індекс мінералізації через 21 добу був меншим від контрольних показників на $51,7 \%(p<0,05)$.

Висновок. Ішемія-реперфузія кінцівки при поєднаній абдоміно-скелетній травмі негативно впливає на репаративні процеси в кістковій тканині, на що вказує різке зменшення індексу мінералізації.

КЛЮЧОВІ СЛОВА: ішемія-реперфузія; поєднана абдоміно-скелетна травма; індекс мінералізації; біохімічні показники.

ВСТУП. Поєднана травма є однією з найчастіших причин смерті, особливо серед постраждалих молодого віку [1, 2]. Також вона впливає на результати довгострокового лікування, викликаючи значний рівень інвалідності, що в основному зумовлено травмами кінцівок $[3,4]$.

Проведені клінічні та експериментальні дослідження показали, що поєднана травма пов'язана зі значно більшим часом загоєння переломів та вищою частотою розвитку ускладнень (c) С. В. Гаріян, 2019. порівняно з ізольованими переломами [5]. Крім того, визначено, що локальна та системна запальна реакція значно впливає на процеси відновлення загоєння переломів [6-9].

До найбільш розповсюджених ускладнень належить остеоартроз, що спричиняє інвалідність, частота якої постійно зростає. Травма, в тому числі суглобів, є важливим фрактором ризику виникнення посттравматичного остеоартриту. Наразі науковці чітко довели негативний вплив системної запальної реакції на розвиток післятравматичного остеоартриту [10-13]. Однак 
ці дослідження в основному стосуються локальних травм.

Використання кровоспинних джгутів з метою зупинки кровотечі, за даними досліджень, є безпечним та покращує результати лікування [14]. Разом 3 тим, у таких постраждалих можливий розвиток рабдоміолізу та системних змін [15]. Вищевказане може впливати на віддалені результати лікування та розвиток пізніх ускладнень.

Таким чином, віддалені результати використання кровоспинних джгутів у постраждалих 3 поєднаною абдоміно-скелетною травмою $є$ важливим питанням та потребує додаткового вивчення, на що і було спрямоване це дослідження.

Мета дослідження - вивчити вплив ішемії-реперфузії кінцівки на моделі поєднаної абдоміно-скелетної травми та масивної крововтрати на зміни біохімічних показників крові.

МЕТОДИ ДОСЛІДЖЕННЯ. РОбочою гіпотезою експериментальних досліджень є припущення, що використання кровоспинного джгута і подальша реперфузія ішемізованих тканин призводять до значних системних змін з порушенням життєдіяльності внутрішніх органів при поєднаній абдоміно-скелетній травмі на фроні гіповолемічного шоку та можуть стати причиною розвитку змін, що впливають на фрункцію кісткової тканини.

3 метою реалізації поставленої мети на 130-ти нелінійних щурах-самцях масою 190220 г було виконано експериментальні дослідження. Усіх тварин поділили на чотири групи: контрольну (КГ) і три дослідних (ГД). До контрольної групи входили інтактні тварини (10 щурів), до 1-ї дослідної (ГД-1) - тварини, яким моделювали перелом стегна, масивну зовнішню крововтрату та ішемію-реперфузію нижніх кінцівок (40 щурів), до 2-ї дослідної (ГД-2) - тварини, яким моделювали скелетну травму, масивну зовнішню крововтрату і закриту травму органів черевної порожнини (40 щурів), до 3-ї дослідної (ГД-3) - тварини, яким моделювали закриту травму органів черевної порожнини, скелетну травму, масивну зовнішню крововтрату й ішемію-реперфузію нижніх кінцівок (40 щурів).

Усі експерименти з нанесення травм виконували за умов тіопентал-натрієвого знеболювання (40 мг·кг-1 маси). Закритий перелом стегнової кістки моделювали шляхом нанесення однократного дозованого удару спеціально розробленим пристроєм по стегну, який викликав закритий перелом (площина ударного пристрою становила 0,5 см² , сила удару - понад 120 кг/см²), закриту травму органів черевної порожнини шляхом нанесення двох дозованих ударів у ді- лянку черевної порожнини спеціально розробленим пристроєм. Силу удару пристрою розраховували таким чином, щоб викликати закриту травму органів черевної порожнини без масивної крововтрати (площина ударного пристрою стано-

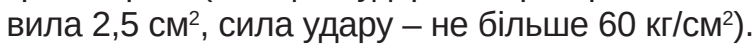
За таких параметрів виникали внутрішньоорганні гематоми з ушкодженням паренхіми і дрібних внутрішньоорганних кровоносних судин, а також забої та невеликі радіальні розриви паренхіматозних органів.

Масивну зовнішню крововтрату моделювали шляхом виконання достатнього операційного доступу до стегнових судин на протилежному від перелому стегнової кістки боці, далі під судинний пучок заводили лігатуру та розсікали судини. Після цього здійснювали забір 20-22 \% циркулюючої крові протягом 1 хв (гостра крововтрата). Кров забирали шляхом просочування та зважування ватного спонжика. Одразу після відбору достатньої кількості крові кровотечу зупиняли шляхом зав'язування лігатур.

Під час експериментів використовували модифрікацію широкого еластичного кровоспинного джгута торговельної марки "SWAT®" виробництва США. Попередньо перед накладанням 3 оригінального полотна кровоспинного джгута вирізали смужку шириною 1,5 см та довжиною 10,0 см. Достатнє розтягнення джгута для повного перетискання судин нижньої лапки тварин контролювали за допомогою спеціальних індикаторів, які виробник наніс на його поверхню.

Тварин виводили з експерименту через 3, 7, 14 та 21 добу після моделювання травм. Під тіопентал-натрієвим знеболюванням здійснювали забій усіх щурів відповідної групи методом тотального кровопускання із серця [16].

У сироватці крові тварин визначали такі біохімічні показники: рівень лужної (ЛФ) і кислої (КФ) фоссратаз [17] та індекс мінералізації (IM) [18]. Досліджували їх у Центральній науковій лабораторії Тернопільського державного медичного університету імені І. Я. Горбачевського.

Достовірність відмінностей між контрольною і дослідними групами оцінювали з використанням непараметричного критерію Манна-Уїтні. Відмінності вважали істинними при вірогідності нульової гіпотези менше $5 \%(p<0,05)$.

РЕЗУЛЬТАТИ Й ОБГОВОРЕННЯ. АналіЗ рівня ЛФ у сироватці крові піддослідних тварин показав, що внаслідок змодельованих травм він зростав у всі терміни спостереження (табл. 1). У ГД-1 достовірно $(p<0,05)$ перевищував контрольні показники: через 3 доби - на 42,4\%, через 7 діб - на 58,9 \%, через 14 діб - на 37,2 \%, через 21 добу - на 60,1 \%. У ГД-2 рівень ЛФ 
Таблиця 1 - Рівень лужної фосфратази (Од/л) у сироватці крові білих щурів за умов моделювання травми в динаміці у групах дослідження (Me (LQ; UQ) - медіана (нижній і верхній квартилі))

\begin{tabular}{|c|c|c|c|c|c|}
\hline \multirow{2}{*}{$\begin{array}{c}\text { Група } \\
\text { дослідження }\end{array}$} & \multirow{2}{*}{ Контроль } & \multicolumn{4}{|c|}{ "Термін дослідження, доба } \\
\hline & & 3-тя & 7-ма & 14-та & 21-ша \\
\hline ГД-1 & \multirow[t]{3}{*}{$\begin{array}{c}501,0 \\
(497,8 ; 508,9) \\
(n=10)\end{array}$} & $\begin{array}{c}713,6^{\star} \\
(701,2 ; 750,4) \\
(n=10)\end{array}$ & $\begin{array}{c}796,4^{*} \\
(773,0 ; 815,8) \\
(n=10)\end{array}$ & $\begin{array}{c}687,3^{*} \\
(618,3 ; 710,6) \\
(n=10)\end{array}$ & $\begin{array}{c}802,0^{*} \\
(769,4 ; 806,6) \\
(n=10)\end{array}$ \\
\hline ГД-2 & & $\begin{array}{c}840,2^{\star} \\
(775,8 ; 888,8) \\
(n=8)\end{array}$ & $\begin{array}{c}957,9^{*} \\
(905,6 ; 1001,0) \\
(n=8)\end{array}$ & $\begin{array}{c}786,0^{\star} \\
(782,2 ; 821,3) \\
(n=8)\end{array}$ & $\begin{array}{c}913,4^{*} \\
(885,9 ; 963,5) \\
(n=8)\end{array}$ \\
\hline ГД-3 & & $\begin{array}{c}914,5^{\star} \\
(902,5 ; 1121,6) \\
(n=7)\end{array}$ & $\begin{array}{c}1262,0^{\star} \\
(1209,3 ; 1384,5) \\
(n=6)\end{array}$ & $\begin{array}{c}1162,6^{\star} \\
(1049,0 ; 1197,7) \\
(n=6)\end{array}$ & $\begin{array}{c}1489,0^{*} \\
(1332,6 ; 1598,3) \\
(n=6)\end{array}$ \\
\hline \multicolumn{2}{|c|}{$p_{1-2}$} & $<0,01$ & $<0,001$ & $<0,001$ & $<0,001$ \\
\hline \multicolumn{2}{|c|}{$p_{1-3}$} & $<0,01$ & $<0,001$ & $<0,001$ & $<0,001$ \\
\hline \multicolumn{2}{|c|}{$p_{2-3}$} & $<0,01$ & $<0,001$ & $<0,001$ & $<0,001$ \\
\hline
\end{tabular}

Примітки. Тут і в таблицях 2, 3:

1. * - відмінності стосовно контрольної групи статистично достовірні $(p<0,05)$.

2. $\mathrm{p}_{1-2}$ - достовірність відмінностей між 1-ю та 2-ю дослідними групами.

3. $\mathrm{p}_{1-3}$ - достовірність відмінностей між 1-ю та 3-ю дослідними групами.

4. $\mathrm{p}_{2-3}$ - достовірність відмінностей між 2-ю та 3-ю дослідними групами.

збільшився: через 3 доби - на 67,7 \% (р<0,05), через 7 діб - на 91,2\% ( $<<0,05)$, через 14 діб - на $56,9 \%(p<0,05)$, через 21 добу післятравматичного періоду - на 82,3\% (p<0,05). У гД-3 під час усього спостереження він був достовірно вищим $(p<0,05)$ від контрольних показників: через 3 доби - на 82,5\%, через 7 діб - на 151,9\%, через 14 діб - на 132,1 \%, через 21 добу - на 197,2 \%.

При порівнюванні рівня ЛФ у дослідних групаху контрольних точках спостереження було встановлено, що в ГД-1 через 3 доби цей показник виявився статистично меншим, ніж у ГД-2 і ГД-3, відповідно, на $17,7 \%\left(\mathrm{p}_{1-2}<0,01\right)$ та $28,2 \%$ $\left(\mathrm{p}_{1-3}<0,01\right)$, у ГД-3 - статистично більшим, ніж у ГД-2, на 8,8 \% ( $\left.\mathrm{p}_{2-3}<0,01\right)$. Через 7 діб спостерігали аналогічну тенденцію: рівень ЛФ у ГД-3 був достовірно вищим порівняно з ГД-1 і ГД-2, відповідно, на 58,5\% $\left(\mathrm{p}_{1-3}<0,001\right)$ та $31,7 \%$ $\left(\mathrm{p}_{2-3}<0,001\right)$, у ГД-1 - нижчим, ніж у ГД-2, на $20,3 \%$, що виявилось статистично достовірним $\left(p_{1-2}>0,001\right)$. Через 14 діб післятравматичного періоду в усіх групах спостерігали зменшення показника порівняно з попереднім значенням, однак у ГД-3 він був статистично більшим від таких у ГД-1 і ГД-2, відповідно, на 69,2 \% $\left(p_{1-3}<0,001\right)$ та $47,9 \%\left(p_{2-3}<0,001\right)$, у ГД-1 - меншим, ніж у ГД-2, на 14,4 \% $\left(\mathrm{p}_{1-2}<0,001\right)$. Через 21 добу післятравматичного періоду рівень ЛФ продовжував зростати у групах дослідження. Так, у ГД-3 він перевищував показники у ГД-1 і ГД-2, відповідно, на 85,7 \% $\left(\mathrm{p}_{1-3}<0,001\right)$ та 63,1 \% $\left(\mathrm{p}_{2-3}<0,001\right)$, у ГД-2 - був більшим від такого у ГД-1 на $13,8 \%\left(p_{1-2}<0,001\right)$.

При аналізі динаміки змін показника ЛФ у дослідних групах встановлено, що у ГД-1 він мав коливальні зміни протягом спостереження. Так, через 7 діб перевищував рівень через 3 доби на $11,6 \%$ ( $p<0,05)$, до 14-ї доби знизився на 13,7 \% $(p<0,05)$, до 21-ї доби зріс на 16,7 \% $(p<0,05)$ та був максимальним під час усього спостереження. Аналогічну тенденцію спостерігали й у ГД-2: через 7 діб показник збільшився на 14,1 \% $(p<0,05)$ відносно рівня ЛФ через 3 доби, до 14-ї доби зменшився щодо рівня через 7 діб на 17,9 \% $(p<0,05)$ та до 21-ї доби підвищився на 16,2 \% стосовно показника через 14 діб, що виявилось статистично достовірним $(p<0,05)$. У ГД-3 зміни показника також мали коливальний характер з тенденцією до зростання до кінця спостереження. Через 7 діб рівень ЛФ збільшився відносно показника через 3 доби на 37,9 \% $(p<0,05)$, незначно знизився через 14 діб - на 7,8 \% (р>0,05) та до 21-ї доби підвищився на $28,1 \%(p<0,05)$.

Рівень КФ у сироватці крові піддослідних тварин також зростав (табл. 2). Так, у ГД-1 він достовірно $(p<0,05)$ перевищував контрольні показники: через 3 доби - на $126,5 \%$, через 7 діб - на 150,9 \%, через 14 діб - на 106,4 \%, через 21 добу - на 116,2 \%. У ГД-2 показник збільшився: через 3 доби - на 155,4 \% $(p<0,05)$, через 7 діб - на 183,3 \% ( $<<0,05)$, через 14 діб на $152,5 \%(p<0,05)$, через 21 добу післятравматичного періоду - на 183,3 \% $(p<0,05)$. У ГД-3 під час усього спостереження рівень КФ був достовірно вищим $(p<0,05)$ від контрольних показників: через 3 доби - на 228,9 \%, через 7 діб - на 362,7 \%, через 14 діб - на 375,9 \%, через 21 добу - на $533,8 \%$.

При порівнюванні рівня КФ у дослідних групах у контрольних точках спостереження було встановлено, що в ГД-1 через 3 доби цей показ- 
Таблиця 2 - Рівень кислої фоссратази (Од/л) у сироватці крові білих щурів за умов моделювання травми в динаміці у групах дослідження (Me (LQ; UQ) - медіана (нижній і верхній квартилі))

\begin{tabular}{|c|c|c|c|c|c|}
\hline \multirow{2}{*}{$\begin{array}{c}\text { Група } \\
\text { дослідження }\end{array}$} & \multirow{2}{*}{ Контроль } & \multicolumn{4}{|c|}{ Термін дослідження, доба } \\
\hline & & 3-тя & 7-ма & 14-та & 21-ша \\
\hline ГД-1 & \multirow[t]{3}{*}{$\begin{array}{c}20,4 \\
(18,6 ; 21,6) \\
(n=10)\end{array}$} & $\begin{array}{c}46,2^{\star} \\
(44,1 ; 47,1) \\
(n=10)\end{array}$ & $\begin{array}{c}51,2^{*} \\
(48,2 ; 53,9) \\
(n=10)\end{array}$ & $\begin{array}{c}42,1^{*} \\
(35,2 ; 48,4) \\
(n=10)\end{array}$ & $\begin{array}{c}44,1^{*} \\
(35,7 ; 47,6) \\
(n=10)\end{array}$ \\
\hline ГД-2 & & $\begin{array}{c}52,1^{*} \\
(47,7 ; 53,7) \\
(n=8)\end{array}$ & $\begin{array}{c}57,8^{\star} \\
(54,0 ; 59,6) \\
(n=8)\end{array}$ & $\begin{array}{c}51,5^{\star} \\
(50,2 ; 61,6) \\
(n=8)\end{array}$ & $\begin{array}{c}57,8^{*} \\
(54,0 ; 59,6) \\
(n=8)\end{array}$ \\
\hline ГД-3 & & $\begin{array}{c}67,1^{*} \\
(61,6 ; 81,3) \\
(n=7)\end{array}$ & $\begin{array}{c}94,4^{\star} \\
(90,7 ; 100,4) \\
(n=6)\end{array}$ & $\begin{array}{c}97,1^{*} \\
(92,4 ; 103,1) \\
(n=6)\end{array}$ & $\begin{array}{c}129,3^{*} \\
(127,0 ; 136,9) \\
(n=6)\end{array}$ \\
\hline \multicolumn{2}{|c|}{$\mathrm{p}_{1-2}$} & $<0,05$ & $<0,001$ & $<0,05$ & $<0,001$ \\
\hline \multicolumn{2}{|c|}{$p_{1-3}$} & $<0,001$ & $<0,001$ & $<0,001$ & $<0,001$ \\
\hline \multicolumn{2}{|c|}{$p_{2-3}$} & $<0,01$ & $<0,001$ & $<0,001$ & $<0,001$ \\
\hline
\end{tabular}

ник виявився статистично меншим, ніж у ГД-2 і ГД-3, відповідно, на 12,7 \% $\left(\mathrm{p}_{1-2}<0,05\right)$ та $45,2 \%$ $\left(\mathrm{p}_{1-3}<0,001\right)$, у ГД-3 - статистично більшим, ніж у ГД-2, на $28,8 \%\left(\mathrm{p}_{2-3}<0,01\right)$. Через 7 діб спостерігали аналогічну тенденцію: рівень КФ у гД-3 був достовірно вищим порівняно з ГД-1 і ГД-2, відповідно, на 84,4\% ( $\left.\mathrm{p}_{1-3}<0,001\right)$ та 63,3\% $\left(\mathrm{p}_{2-3}<0,001\right)$, у ГД-1 - нижчим, ніж у ГД-2, на $12,9 \%$, що виявилось статистично достовірним $\left(\mathrm{p}_{1-2}<0,001\right)$. Через 14 діб післятравматичного періоду в ГД-1 та ГД-2 спостерігали зменшення показника порівняно з попереднім значенням, у ГД-3 він збільшувався та був статистично вищим від таких у ГД-1 і ГД-2, відповідно, на 130,6 \% $\left(p_{1-3}<0,001\right)$ та $88,5 \%\left(p_{2-3}<0,001\right)$, у ГД-1 - нижчим, ніж у ГД-2, на $22,3 \%\left(p_{1-2}<0,05\right)$. Через 21 добу післятравматичного періоду рівень КФ зріс у групах дослідження. Так, у ГД-3 він перевищував показники у ГД-1 і ГД-2, відповідно, на $193,2 \%\left(p_{1-3}<0,001\right)$ та $123,7 \%\left(p_{2-3}<0,001\right)$, у ГД-2 - був більшим від такого у ГД-1 на 31,1 \% $\left(p_{1-2}<0,001\right)$.

При аналізі динаміки змін показника КФ у дослідних групах встановлено, що у ГД-1 він мав коливальні зміни протягом спостереження. Так, через 7 діб перевищував рівень через 3 доби на 10,8 \% (p<0,05), до 14-ї доби знизився на 17,8 \% $(p<0,05)$, до 21-ї доби зріс на 4,8 \% ( $>>0,05)$. Аналогічну тенденцію спостерігали й у ГД-2: через 7 діб показник збільшився на 10,9\% $(p<0,05)$ відносно рівня КФ через 3 доби, до 14-ї доби зменшився щодо рівня через 7 діб на $10,9 \%(p<0,05)$ та до 21-ї доби підвищився на 12,2 \% стосовно показника через 14 діб, що виявилось статистично достовірним $(\mathrm{p}<0,05)$. У ГД-3 зміни показника також мали характер односпрямованого зростання до кінця спостереження. Через 7 діб рівень КФ збільшився відносно показника через 3 доби на 40,7 \% ( $<<0,05)$, через 14 діб - на 2,9 \% (p>0,05) та до 21-ї доби підвищився на $33,2 \%(p<0,05)$ щодо попереднього.

Після дослідження рівня ензимів ЛФ і КФ у крові та гомогенаті кістки піддослідних тварин було проаналізовано індекс мінералізації.

Індекс мінералізації, вирахуваний на основі аналізу рівня ензимів у сироватці крові піддослідних тварин (табл. 3), у ГД-1 був достовірно меншим від контрольного показника протягом усього спостереження $(p<0,05)$. Так, через 3 доби - на 31,9 \%, через 7 діб - на 36,1\%, через 14 діб - фрактично залишався на попередньому рівні та через 21 добу дещо зростав, однак був нижчим від контрольного показника на 26,1%.

Таблиця 3 - Індекс мінералізації (ум. од.) у крові білих щурів за умов моделювання травми в динаміці у групах дослідження (Me (LQ; UQ) - медіана (нижній і верхній квартилі))

\begin{tabular}{|c|c|c|c|c|c|}
\hline \multirow{2}{*}{$\begin{array}{c}\text { Група } \\
\text { дослідження }\end{array}$} & \multirow{2}{*}{ Контроль } & \multicolumn{4}{|c|}{ Термін дослідження, доба } \\
\hline & & 3-тя & 7-ма & 14-та & 21-ша \\
\hline ГД-1 & \multirow{4}{*}{$\begin{array}{c}23,8 \\
(23,4 ; 26,4) \\
(n=10)\end{array}$} & $16,6^{*}$ & $15,2^{*}$ & $15,1^{*}$ & $17,6^{*}$ \\
\hline & & $(15,3 ; 17,3)(n=10)$ & $(14,6 ; 17,0)(n=10)$ & $(14,3 ; 18,5)(n=10$ & $(17,2 ; 21,7)(n=10)$ \\
\hline ГД-2 & & $\begin{array}{c}15,7^{*} \\
(14,7 ; 17,0)(n=8)\end{array}$ & $\begin{array}{c}14,5^{*} \\
(13,8 ; 15,4)(n=8)\end{array}$ & $\begin{array}{c}15,3^{*} \\
(13,5 ; 15,6)(n=8)\end{array}$ & $\begin{array}{c}16,3^{*} \\
(15,5 ; 17,4)(n=8)\end{array}$ \\
\hline ГД-3 & & $\begin{array}{c}14,0^{*} \\
(13,8 ; 14,3)(n=7)\end{array}$ & $\begin{array}{c}13,5^{\star} \\
(13,2 ; 13,7)(n=6)\end{array}$ & $\begin{array}{c}11,9^{*} \\
(11,4 ; 12,1)(n=6)\end{array}$ & $\begin{array}{c}11,5^{\star} \\
(11,0 ; 12,1)(n=6)\end{array}$ \\
\hline \multicolumn{2}{|c|}{$p_{1-2}$} & $>0,05$ & $>0,05$ & $>0,05$ & $<0,05$ \\
\hline \multicolumn{2}{|c|}{$p_{1-3}$} & $<0,01$ & $<0,01$ & $<0,001$ & $<0,001$ \\
\hline \multicolumn{2}{|c|}{$p_{2-3}$} & $<0,01$ & $<0,01$ & $<0,001$ & $<0,001$ \\
\hline
\end{tabular}


У ГД-2 через 3 доби після моделювання травми рівень IM різко зменшився відносно контрольного показника - на $34,1 \%(p<0,05)$ та зазнавав незначних коливальних змін протягом спостереження в контрольних точках: через 7 діб був нижчим на 39,1 \% $(p<0,05)$, через 14 діб - на $35,7 \%$ ( $<<0,05)$, через 21 добу - на 31,5\% $(p<0,05)$. У ГД-3 показник IM односпрямовано зменшувався до 21-ї доби спостереження відносно контролю та був достовірно нижчим на 41,2, 43,3, 49,9 і 51,7 \%, відповідно, через 3, 7, 14 та 21 добу $(p<0,05)$.

При порівнюванні показника IM у дослідних групах за термінами спостереження було встановлено, що в ГД-3 через 3 доби він виявився статистично нижчим, ніж у ГД-1 і ГД-2, відповідно, на $13,6 \%\left(p_{1-3}<0,01\right)$ та $10,8 \%\left(p_{2-3}<0,01\right)$. Також у ГД-2 показник був меншим від такого у ГД-1 на 3,1 \% ( $\left.p_{1-2}>0,05\right)$. Через 7 діб рівень IM у ГД-3 залишався нижчим порівняно з ГД-1 та ГД-2, відповідно, на 11,2 \% ( $\left.p_{1-3}<0,01\right)$ та 6,9 \% $\left(\mathrm{p}_{2-3}<0,01\right)$. Різницю також спостерігали між показниками в ГД-1 та ГД-2, однак вона не була достовірною, рівень ІМ у ГД-1 перевищував такий у ГД-2 на 4,6 \% ( $\left.p_{1-2}>0,05\right)$. Через 14 діб відзначали аналогічну тенденцію, і в ГД-З величина IM виявилась суттєво меншою, ніж у ГД-1 та ГД-2, відповідно, на 21,2 \% ( $\left.p_{1-3}<0,001\right)$ і $22,2 \%$ $\left(\mathrm{p}_{2-3}<0,001\right)$. Також у ГД-1 та ГД-2 показник IM був фрактично на одному рівні $\left(p_{1-2}>0,05\right)$. Через 21 добу післятравматичного періоду спостерігали тенденцію, як і в попередніх точках дослідження, однак різниця показника IM у групах дослідження зростала. Так, у ГД-3 рівень IM був достовірно найменшим порівняно з ГД-1 та ГД-2, відповідно, на 34,7 \% ( $\left.p_{1-3}<0,001\right)$ і 29,4\% $\left(p_{2-3}<0,001\right)$. Аналіз показав, що IM у ГД-1 був більшим, ніж у ГД-2, на 7,4 \% $\left(\mathrm{p}_{2-3}<0,05\right)$.

При аналізі динаміки змін рівня IM у групах піддослідних тварин встановлено, що у ГД-1 він досягав максимального значення через 24 доби: через 7 діб був меншим від показника через 3 доби на 6,2 \% (p>0,05), у подальшому спостерігали його незначне зниження до 14-ї доби, надалі зростав до 21-ї доби на 16,5 \% $(p<0,05)$. У ГД-2 рівень ІМ зазнавав коливальних змін протягом спостереження: через 7 діб був меншим від показника через 3 доби на 7,6 \% $(p>0,05)$, після чого збільшувався до 14-ї доби на 5,5 \% (p>0,05), до 21-ї доби - на 6,5 \% (p>0,05). У ГД-3 рівень ІМ односпрямовано знижувався до кінця спостереження: через 7 діб зменшувався на $3,6 \%(p>0,05)$ порівняно 3 показником через 3 доби, через 14 діб був нижчим на 11,9 \% ( $>>0,05)$ відносно показника через 7 діб та фрактично залишався на такому рівні до кінця 21-ї доби.

ВИСНОВКИ. 1. Ішемія-реперфузія кінцівки на моделі поєднаної абдоміно-скелетної травми має потенціювальну дію на зміни показників лужної та кислої фоосфатаз, що проявляється значним зростанням їх активності протягом 21-ї доби післятравматичного періоду.

2. Зміни показника індексу мінералізації в піддослідних тварин свідчить про негативний вплив ішемії-реперфузії на репаративні процеси у кістковій тканині.

Перспективи подальших досліджень. У перспективі передбачається розробити патогенетично обґрунтовані засоби корекції системних змін, що виникають під впливом реперфузії кінцівки та впливають на зміни в кістковій тканині.

\section{СПИСОК ЛІТЕРАТУРИ}

1. National trauma data bank - annual report / M. L. Nance ed. NTDB Annual Report, American College of Surgeon, 2013.

2. Lefering R. Trauma Register DGU. Annual Report 2014 / R. Lefering, T. Paffrath, U. Nienaber. Sektion NIS of the German Trauma Society (DGU). Köln, Germany. 2013.

3. Epidemiology of extremity injuries in multiple trauma patients / M. Banerjee, B. Bouillon, S. Shafizadeh [et al.] // Injury. - 2013. - 44 (8). - P. 1015-1021.

4. Health-related quality of life in patients with multiple injuries and traumatic brain injury $10+$ years postinjury / J. Steel, M. Youssef, R. Pfeifer [et al.] // Journal of Trauma-Injury Infection \& Critical Care. -2010. - 69 (3). P. 523-530.
5. The influence of fracture etiology and type on fracture healing: a review of 104 consecutive tibial shaft fractures / A. Karladani, H. Granhed, J. Kärrholm, J. Styf // Arch. Orthop. Trauma Surg. - 2001 - 121 (6). - P. 325328.

6. Tsunoda M. The osteogenic potential of fracture hematoma and its mechanism on bone formation through fracture hematoma culture and transplantation of freeze-dried hematoma / M. Tsunoda, K. Mizuno, T. Matsubara // Kobe Journal of Medical Sciences. 1993. - 39 (1). - P. 35-50.

7. Effect of repeated irrigation and debridement on fracture healing in an animal model / S.-H. Park, M. Silva, W.-J. Bahk [et al.] // Journal of Orthopaedic Research. 2002. - 20 (6). - P. 1197-1204. 
8. Grundnes O. Effects of macrophage activation on bone healing / O. Grundnes, O. Reikeraas // Journal of Orthopaedic Science. - 2000. - 5 (3). - P. 243-247.

9. Inflammation - a double edged sowrd in highenergy fractures? / R. J. Bunn, G. Burke, C. Conelly [et al.] // The Bone \& Joint Journal. - 2005. - 87 (3). P. 265-266.

10. Epidemiology of posttraumatic osteoarthritis / A. C. Thomas, T. Hubbard-Turner, E. A. Wikstrom, R. M. Palmieri-Smith // J. Athl. Train. - 2017. - 52 (6). P. 491-496.

11. Johnson V. L. The epidemiology of osteoarthritis / V. L. Johnson, D. J. Hunter // Best Pract Res Clin Rheumatol. - 2014. - No. 28. - P. 5-15.

12. Volotovska N. V. Changes in the glutathione system's activity of internal organs in the first hours of experimental limb ischemia-reperfusion syndrome, combined with blood loss and mechanical injury / N. V. Volotovska, T. C. Nhokwara, I. V. Zhulkevych // Здобутки клінічної і експериментальної медицини. - 2019. № 1. - C. 23-27. DOI 10.11603/1811-2471.2019.v0. i1.10043

13. Комплексне експериментальне дослідження іммобілізаційної моделі остеопорозу / Л. Я. Ковальчук, М. С. Гнатюк, С. І. Сміян [та ін.] // Вісн. наук. дослідж. 2000. - № 1. - C. 81-84.

\section{REFERENCES}

1. Nance, M.L. (Ed.). (2013). National trauma data bank - annual report. NTDB Annual Report, American College of Surgeon.

2. Lefering, R., Paffrath, T., \& Nienaber, U. (2013). Trauma Register DGU. Annual Report 2014. Sektion NIS of the German Trauma Society (DGU). Köln, Germany.

3. Banerjee, M., Bouillon, B., Shafizadeh, S., Paffrath, T., Lefering, R., \& Wafaisade, A. (2013). Epidemiology of extremity injuries in multiple trauma patients. Injury, 44 (8), 1015-1021.

4. Steel, J., Youssef, M., Pfeifer, R., Ramirez, J.M., Probst, C., Sellei, R., .., \& Pape, H.C. (2010). Healthrelated quality of life in patients with multiple injuries and traumatic brain injury 10+ years postinjury. Journal of Trauma-Injury Infection \& Critical Care, 69 (3), 523-530.

5. Karladani, A., Granhed, H., Kärrholm, J., \& Styf, J. (2001). The influence of fracture etiology and type on fracture healing: a review of 104 consecutive tibial shaft fractures. Arch Orthop Trauma Surg, 121 (6), 325-328.

6. Tsunoda, M., Mizuno, K., \& Matsubara, T. (1993). The osteogenic potential of fracture hematoma and its mechanism on bone formation - through fracture hematoma culture and transplantation of freeze-dried hematoma. Kobe Journal of Medical Sciences, 39 (1), 35-50.

7. Park, S.H., Silva, M., Bahk, W.J., McKellop, H., \& Lieberman, J.R. (2002). Effect of repeated irrigation and debridement on fracture healing in an animal model. Journal of Orthopaedic Research, 20 (6), 1197-1204.

8. Grundnes, O., \& Reikeraas, O. (2000). Effects of macrophage activation on bone healing. Journal of Orthopaedic Science, 5 (3), 243-247.
14. Prehospital tourniquet use in penetrating extremity trauma / A. A. Smith, J. E. Ochoa, S. Wong [et al.] // Journal of Trauma and Acute Care Surgery. - 2019. 86 (1). - P. 43-51.

15. Kauvar D. S. Tourniquet use is not associated with limb loss following military lower extremity arterial trauma / D. S. Kauvar, D. M. Miller, T. J. Walters // Journal of Trauma and Acute Care Surgery. - 2018. - 85 (3). P. 495-499.

16. Защитные свойства микрокристаллической целлюлозы при экспериментальном сахарном диабете у крыс / С. Г. Вайнштейн, И. В. Жулкевич, Г. А. Петропавловский, Н. Е. Котельникова // Бюлл. эксперим. биологии и медицины. - 1987. - 103, вып. 2. - С. 167-168.

17. Левицкий А. П. Экспериментальные методы исследования стимуляторов остеогенеза : метод. рек. / А. П. Левицкий, О. А. Макаренко, О.В.Деньга. К. : ГФЦ, 2005. - 30 с.

18. Березовская О. П. Остеогенез в условиях гипокинезии и гипоксии / О. П. Березовская, И. Г. Литовка // Проблеми екологічної та медичної генетики і клінічної імунології : зб. наук. пр. - К. ; Луганськ ; Харків, 2002. - Вип. 6 (45). - С. 19-31.

9. Bunn, R.J., Burke, G., Connelly, C., Li, G., \& Marsh, D. (2005). Inflammation - a double edged sowrd in high-energy fractures? The Bone \& Joint Journal, 87 (3), 265-266.

10. Thomas, A.C., Hubbard-Turner, T., Wikstrom, E.A., \& Palmieri-Smith, R.M. (2017). Epidemiology of Posttraumatic Osteoarthritis. J. Athl. Train., 52 (6), 491-496.

11. Johnson, V.L., \& Hunter, D.J. (2014). The epidemiology of osteoarthritis. Best Pract. Res. Clin. Rheumatol., 28, 5-15.

12. Volotovska, N.V., Nhokwara, T.C., \& Zhulkevych, I.V. (2019). Changes in the glutathione systems activity of internal organs in the first hours of experimental limb ischemia-reperfusion syndrome, combined with blood loss and mechanical injury. Zdobutky klinichnoi i eksperymentalnoi medytsyny-Achievements of Clinical and Experimental Medicine, 1, 23-27. DOI 10.11603/18112471.2019.v0.i1.10043

13. Kovalchuk, L.Ya., Hnatyiuk, M.S., Smiian, S.I., Zhulkevych, I.V., Masyk, O.M., Hudyma, A.A., \& Lisnychuk, N.Ye. (2000). Kompleksne eksperymentalne doslidzhennia immobilizatsiinoi modeli osteoporozu [Complex experimental study of immobilization model of osteoporosis]. Visnyk naukovykh doslidzhen - Bulletin of Scientific Research, 1, 81-84 [in Ukrainian].

14. Smith, A.A., Ochoa, J.E., Wong, S., Beatty, S., Elder, J., Guidry, C., ..., \& Schroll, R. (2019). Prehospital tourniquet use in penetrating extremity trauma. Journal of Trauma and Acute Care Surgery, 86 (1), 43-51. 
15. Kauvar, D.S., Miller, D.M., \& Walters, T.J. (2018). Tourniquet use is not associated with limb loss following military lower extremity arterial trauma. Journal of Trauma and Acute Care Surgery, 85 (3), 495-499.

16. Vaynshteyn, S.G., Zhulkevich, I.V., Petropavlovskiy, G.A., \& Kotelnikova, N.E. (1987). Zashchitnyye svoystva mikrokristallicheskoy tsellyulozy pri eksperimentalnom sakharnom diabete u krys [Protective properties of microcrystalline cellulose in experimental diabetes mellitus in rats]. Byull. eksperim. biol. i meditsiny - Bulletin of Experimental Biology and Medicine, 103, 2, 167168 [in Russian].
17. Levitskiy, A.P., Makarenko, O.A., \& Denga, O.V. (2005). Eksperimentalnyye metody issledovaniya stimulyatorov osteogeneza: Metod. rekomendatsii [Experimental methods for the study of stimulators of osteogenesis: Method. Recommendations]. Kyiv: GFTS [in Ukrainian].

18. Berezovskaya, O.P., \& Lytovka, I.G. (2002). Osteogenez v usloviyakh gipokinezy i gipoksii [Osteogenesis in conditions of hypokinesia and hypoxia]. Problemy ekolohichnoi ta medychnoi henetyky i klinichnoi imunolohii. Zbirnyk naukovykh prats - Problems of Environmental and Medical Genetics and Clinical Immunology. Collection of Scientific Works, 6 (45), 19-31 [in Russian].

\section{ОСОБЕННОСТИ ИЗМЕНЕНИЙ БИОХИМИЧЕСКИХ ПОКАЗАТЕЛЕЙ КРОВИ ПОДОПЫТНЫХ ЖИВОТНЫХ В РЕЗУЛЬТАТЕ СОЧЕТАННОЙ АБДОМИНО- СКЕЛЕТНОЙ ТРАВМЫ И ИШЕМИИ-РЕПЕРФУЗИИ НИЖНИХ КОНЕЧНОСТЕЙ}

\section{Резюме}

Вступление. Сочетанная травма - важный вопрос современной медицины, поскольку является основной причиной смерти и длительной потери трудоспособности среди лиц молодого возраста. К самым распространенным осложнениям относят остеоартроз, который вызывает инвалидность. Неблагоприятным фрактором, влияющим на его развитие, является ишемия-реперфузия конечности, однако ее влияние требует дополнительного изучения.

Цель исследования - изучить влияние ишемии-реперфузии конечности на модели соченанной абдомино-скелетной травмы и массивной кровопотери на изменения биохимических показателей крови.

Методы исследования. Работа имеет экспериментальный характер, ее выполняли на 130-ти половозрелых белых крысах-самцах линии Вистар. Всех животных разделили на четыре группы: контрольную и три исследовательских. В контрольную группу входили интактные животные, в 1-ю исследовательскую - крысы, которым моделировали перелом бедра, массивную внешнюю кровопотерю и ишемию-реперфузию нижних конечностей, во 2-ю исследовательскую - животные, которым моделировали скелетную травму, массивную внешнюю кровопотерю и закрытую травму органов брюшной полости, в 3-ю исследовательскую - крысы, которым моделировали закрытую травму органов брюшной полости, скелетную травму, массивную внешнюю кровопотерю и ишемию-реперфузию нижних конечностей. Животных исследовательских групп выводили из эксперимента через 3, 7, 14 и 21 сутки после моделирования травм. В сыворотке крови подопытных животных определяли уровень щелочной и кислой фросфатаз и на основе этих данных рассчитывали индекс минерализации.

Результаты и обсуждение. У подопытных животных всех групп наблюдали длительное возрастание активности щелочной и кислой фоссратаз и, как следствие, индекса минерализации. Выявлено однотипность в динамике изменений исследуемых показателей у крыс 1-й и 2-й исследовательских групп. В группе подопытных животных, которым моделировали абдомино-скелетную травму, массивную кровопотерю и ишемию-реперфузию нижних конечностей, их изменения были наиболее выраженными, в частности индекс минерализации через 21 сутки был меньше от контрольных показателей на 51,7 \% $(p<0,05)$.

Вывод. Ишемия-реперфузия конечности при сочетанной абдомино-скелетной травме негативно влияет на репаративные процессы в костной ткани, на что указывает резкое уменьшение индекса минерализации.

КЛЮЧЕВЫЕ СЛОВА: ишемия-реперфузия; сочетанная абдомино-мышечная травма; индекс минерализации; биохимические показатели. 


\section{BLOOD BIOCHEMICAL PARAMETERS CHANGES OF EXPERIMENTAL ANIMALS AS A RESULT OF COMBINED ABDOMINAL SKELETAL TRAUMA AND ISCHEMIA REPERFUSION OF THE LOWER EXTREMITIES}

\section{Summary}

Introduction. Combined trauma is a major cause of death and long-term disability among working-age people. Osteoarthrosis is one of the most common complications. An unfavorable factor affecting the development of complication is ischemia - reperfusion of the limb, but its impact needs further study.

The aim of the study - to learn the effect of limb reperfusion in a model of combined abdominal-skeletal trauma and massive blood loss on changes in blood biochemical parameters.

Research Methods. The work was experimental and was performed on 130 adult white male Wistar rats. Animals were divided into four groups: control (CG) and three experimental (EG): control group; experimental group 1 (EG-1) - modeled a hip fracture, massive external bleeding, and ischemia-reperfusion of the lower extremities; experimental group 2 (EG-2) - modeled for skeletal trauma, massive external blood loss, and closed abdominal trauma; experimental group 3 (EG-3) - modeled closed abdominal trauma, skeletal trauma, massive external blood loss and ischemia-reperfusion of the lower extremities. The animals were removed from the experiment 3, 7, 14 and 21 days after trauma. The levels of alkaline phosphatase, acid phosphatase were determined in the serum of experimental animals and a mineralization index was calculated based on these data.

Results and Discussion. In experimental animals of all groups, a prolonged increase in the activity of alkaline and acid phosphatases and, as a consequence, the mineralization index were observed. Identified uniformity in the dynamics of changes in the studied parameters in rats of experimental groups 1 and 2. In the group of experimental animals that simulated abdomino-skeletal injury, massive blood loss and ischemia-reperfusion of the lower extremities, their changes were most pronounced, in particular, the mineralization index after 21 days was $51.7 \%$ less than the control values $(p<0.05)$.

Conclusion. Ischemia-reperfusion of the extremities with combined abdominal-skeletal injury adversely affects the reparative processes in bone tissue, as indicated by decrease in the index of mineralization.

KEY WORDS: ischemia; reperfusion; combined skeletal trauma; mineralization index; biochemical parameters.

Отримано 05.11.19

Адреса для листування: С. В. Гаріян, Український науково-практичний центр екстреної медичної допомоги та медицини катастрофр МОЗ України, вул. Братиславська, 3, Київ, 02166, Україна, e-mail: disastermed2@ukr.net. 